Q. $\mathrm{LI}^{1}$ and J. YANG ${ }^{1}$

\title{
IMPROVEMENT OF REGIONAL CEREBRAL BLOOD FLOW AFTER STIMULATION OF THE NUCL. FASTIGIUS IN CEREBRAL INFARCTION PATIENTS
}

\author{
Received February 14, 2014
}

Experimental studies reported that focal stimulation of the nucl. fastigius (fastigial nucleus stimulation, FNS) increases regional cerebral blood flow (rCBF) and ameliorates disorders of cerebral blood circulation. The aim of our study was to examine the effect of FNS on $\mathrm{rCBF}$ in cerebral infarction patients and to estimate correlation of the respective effect with prognosis and treatment. The $\mathrm{rCBF}$ of 20 cerebral infarction patients was measured before and after FNS using single-photon emission computed tomography (SPECT), and the data were subjected to semiquantitative analysis. Results of the neural ability defect test were used to evaluate prognosis. In the above patients, different levels of decreased rCBF were observed. Focal FNS noticeably ameliorated disorders of circulation in both the infarction area and the corresponding contralateral cerebral area $(P<0.05)$. The SPECT images showed that the improvement of rCBF was more evident in the central region of the lesion than in the surrounding area. Thus, it was demonstrated that FNS treatment enhances rCBF, which is followed by the improvement of clinical symptoms in cerebral infarction patients.

Keywords: cerebral infarction, regional cerebral blood flow (rCBF), fastigial nucleus, electronic focal stimulation, single-photon emission computed tomography (SPECT).

\section{INTRODUCTION}

As was found in experimental studies, stimulation of the $n u c l$. fastigius (fastigial nucleus stimulation, FNS) increases the intensity of regional cerebral blood flow (rCBF) and ameliorates disorders of cerebral blood circulation. It has also been demonstrated that focal FNS is an effective clinical measure in the treatment of cerebral infarction patients. In our study, semiquantitative analysis of $\mathrm{rCBF}$ measured by singlephoton emission computed tomography (SPECT) was employed to assess the effect of the above stimulation on the improvement of $\mathrm{rCBF}$ in a group of cerebral infarction patients.

\section{METHODS}

Twenty patients with a new diagnosis of acute ischemic cerebral vascular disease were involved in the study. Among them were 12 men and 8 women

\footnotetext{
${ }^{1}$ Department of Neurology, First Affiliated Hospital, Chongqing Medical University, Chongqing, China.

Correspondence should be addressed to J. Yang

(e-mail: yangjun123000@126.com).
}

with an average age of 56.7 years. Some of these patients had complications of hypertension $(n=8)$, diabetes $(n=3)$, and coronary heart disease $(n=4)$. The diagnosis of acute ischemic cerebral vascular disease was supported by findings from computed tomography (CT) or magnetic resonance imaging (MRI) of the head. The duration of disease was less than seven days.

The neural ability defect and history of past illness and complications were assessed for each patient before the treatment was initiated. Cerebral vascular function treatment (CVFT) using FNS was started immediately upon admission to the hospital. After the electrodes were attached to the surface of the mastoid processes, electronic focal stimulation with respect to the fossa posterior was carried out. The electrical current flowed for 30 to $45 \mathrm{~min}$ once a day for two days in toto (attenuation of ${ }^{99} \mathrm{Tc}^{\mathrm{m}}$-ethyl cysteinate dimer, ECD, requires $24 \mathrm{~h}$ ). The parameters of CVFT were the following: mode 3, frequency of 131 to $136 \%$, and intensity adjusted to $50-70 \%$, according to different tolerances from different patients. The SPECT test was carried out in all patients, once before the FNS treatment and then repeated one time after the second treatment. The SPECT examinations were carried out on a Siemens D acam single probe 
SPECT, with low energy, high resolution, and parallel hole collimators. The ${ }^{99} \mathrm{Tc}^{\mathrm{m}}-\mathrm{ECD}$ was used to develop images from the rCBF tomography. The two-step labeling kit for ECD was provided by the Jiang Su Institute of Atomic Energy (China). Oral administration of $400 \mathrm{mg}$ potassium perchlorate was given to fasting patients $1 \mathrm{~h}$ before the SPECT test. After choroid plexuses from the thyroid gland and cerebral ventricle were occluded, the patients were maintained for $10 \mathrm{~min}$ in the prone position with the head secured, the eyes covered with a black patch, and the ears fitted with ear plugs. Then, ${ }^{99} \mathrm{Tc}^{\mathrm{m}}$-ECD was administered by i.v. injection into the cubital veins, the orbito-meatus line (OM line) was kept vertical to the ground, and the probes were rotated at $360^{\circ}$ around the head for tomography imaging. One frame was collected from every 5-6 deg rotation, producing 64 frames altogether that were computationally reconstructed as the images of a cross section, a coronal section, and a sagittal section. For image analysis, the region of interest (ROI) [1,2] was chosen to obtain the image of this region from the lesion area before FNS treatment, and also the ROI region from the opposite area was estimated by a mirror-image method. Average radiation counts and total radiation counts were calculated from each region.

For all patients, the Scandinavian Neurological Stroke Scale (SNSS) was used to calculate the scores of the neural ability defect before and after FNS treatment. Semiquantitative SPECT analysis was employed before and after FNS, and the ROI was chosen to calculate the average radiation counts from the lesion area and opposite regions.
Statistical comparisons of the scores from the neural ability defect test before and after FNS and of average radiation counts $(M \pm$ s.d.) were performed by the paired $t$-test.

\section{RESULTS}

Scores from the Neural Ability Defect Test Before and After FNS. The score after the FNS procedure was found to decrease by 14.28 , as compared to that before this treatment $(P<0.001$; Table 1$)$. This finding indicates that the neural ability noticeably improved due to FNS.

Changes in rCBF Measured by SPECT before and after FNS, as Expressed by the Average Radiation Counts in the ROI Region. There was a significant difference between average radiation counts before and after FNS treatment, and this significance was observed in both the lesion region and the lesionadjacent area $(P<0.05)$ (Table 2, Figs. 1 and 2$)$. These results demonstrate that $\mathrm{rCBF}$ improved noticeably after FNS treatment in both the directly impaired region and the opposite area. However, improvement of $\mathrm{rCBF}$ immediately in the lesion region was more than that in the lesion-adjacent area $(P<0.05)$.

\section{DISCUSSION}

In our study, SPECT was used to evaluate the changes in $\mathrm{rCBF}$ and to examine the neural ability defect after CVFTbased FNS treatment of acute cerebral infarct patients.

T a b l e 1. SNSS scores before and after FNS (means \pm s.d.)

T а б л и ц я 1. Оцінки за шкалою SNSS перед стимуляцісю фастигіального ядра та після неї

\begin{tabular}{lcc}
\hline & Cases, $n$ & SNSS \\
\hline Before FNS & 20 & $42.60 \pm 7.60$ \\
After FNS & 20 & $28.32 \pm 8.10$ \\
\hline
\end{tabular}

$P<\mathbf{0 . 0 0 1}$.

T a b l e 2. rCBF average radiation counts obtained before and after FNS

Т а б л и ц я 2. Усереднені значення інтенсивності випромінення, що відображують інтенсивність регіонального церебрального кровообігу, перед стимуляцією фастигіального ядра та після неї

\begin{tabular}{lccc}
\hline Regions & Cases, $n$ & before FNS & after FNS \\
\hline Lesion & 20 & $50.25 \pm 13.46$ & $65.63 \pm 18.99^{* * \#}$ \\
Lesion-adjacent & 20 & $61.95 \pm 21.40$ & $88.99 \pm 58.07^{*}$ \\
\hline
\end{tabular}

${ }^{*} P<\mathbf{0 . 0 5}$, as compared to before; ${ }^{\#} P<\mathbf{0 . 0 5}$, as compared to the lesion-adjacent region. 


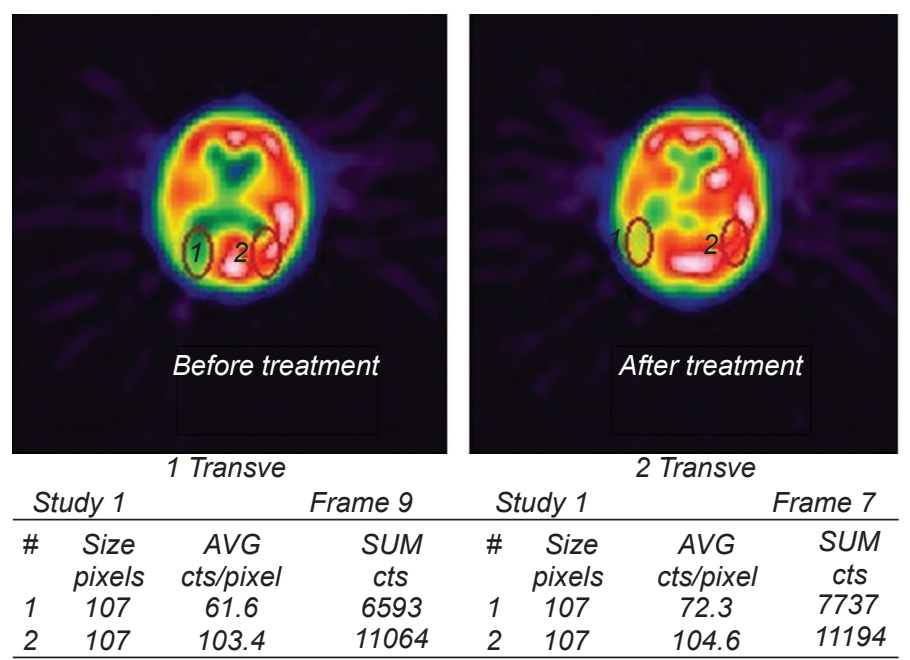

F i g. 1. Changes in regional cerebral blood flow (rCBF) after fastigial nucleus stimulation (FNS) in one of the patients. 1) Lesion region; 2) lesion-adjacent region.

Р и с. 1. Зміни регіонального церебрального кровообігу після стимуляції фастигіального ядра в одного з пацієнтів.

The mechanism and effect of the intuitive nuclear medical imaging technology was investigated. SPECT imaging is known to give reliable references and to provide an effective basis for clinical evaluation of particular treatment measures; the results are characterized by excellent objectivity and sensitivity. In general, changes in $\mathrm{rCBF}$ precede changes in cerebral morphology. The radionuclide imaging technique is more sensitive to variation of blood flow since changes in radiation

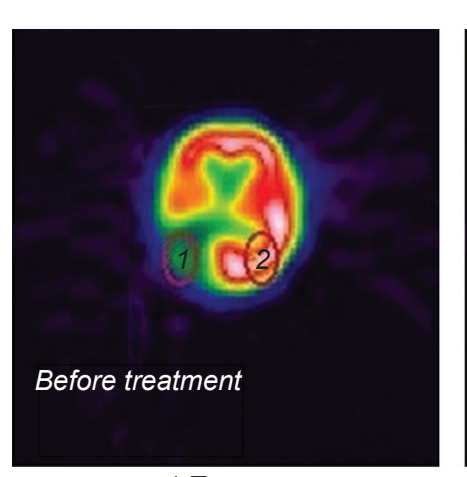

1 Transve

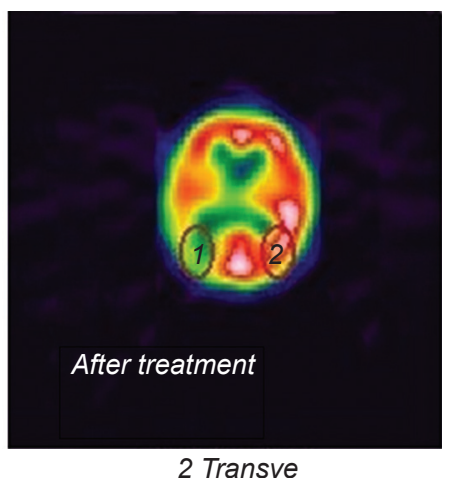

2 Transve

\begin{tabular}{cccccccc}
\multicolumn{2}{c}{ Study 1 } & & Frame 9 & \multicolumn{2}{c}{ Study 2 } & \multicolumn{2}{c}{ Frame 11 } \\
\hline \# & Size & AVG & SUM & $\#$ & Size & AVG & SUM \\
& pixels & cts/pixel & cts & & pixels & cts/pixel & cts \\
1 & 140 & 60.7 & 8504 & 1 & 107 & 98.5 & 13783 \\
2 & 140 & 96.9 & 13562 & 2 & 107 & 255.5 & 35774 \\
\hline
\end{tabular}

F i g. 2. Changes in rCBF after FNS in another patient. 1) Lesion region; 2) Lesion-adjacent region.

Р и с. 2. Зміни регіонального церебрального кровообігу після стимуляції фастигіального ядра в іншого пацієнта. distribution occur upon variations in blood flow within the lesion region. However, the CT scan only recognizes changes in the tissue density in the impaired region. As alterations of the morphology of infarcted tissues in cerebral infarct patients is a relatively slow process, the CT scan is unable to capture the change, even when the clinical symptoms and physical signs are improved in these patients. SPECT imaging, however, overcomes this limitation and is capable of recording different levels of improvements $[2,3]$. The results obtained in our study showed that there was a significant increase in $\mathrm{rCBF}$, both within the lesion region and the lesion-adjacent one, in response to CVFT FNS. In addition, rCBF immediately within the lesion region increased to a greater extent as compared to that in the lesion-adjacent region. As a consequence, the scores from the neural ability defect test were noticeably improved.

Results of our study are consistent with those obtained in animal experiments [4-7] and human clinical studies [8]. The potential mechanisms underlying this process might be the following: (i) CVFT treatment affects the fastigial nucleus, which in turn would modulate the cerebral vascular autoregulatory center; ultimately, $\mathrm{rCBF}$ in the ischemic and penumbra regions would increase [4-6, 8], causing a delay or prevention of neuronal damage, reducing the infarction area, and attenuating cerebral edema. (ii) FNS treatment modulates the neurotransmitter release $[7,9]$. We found that the number of $5-\mathrm{HT}$ immunoreactive cells greatly increased in the lesion region after FNS treatment, suggesting that induction of 5-HT may be involved in increasing rCBF after such a procedure. (iii) Hemorheology amelioration promotes rCBF improvement after FNS treatment [10]. After microcirculation was improved, aggregation and infiltration of leukocytes was observed to be attenuated in the capillaries of the lesion zone. Subsequently, the release inflammatory factor is reduced, and the post-ischemic injury is alleviated. (iv) FNS inhibits expression of mRNA of inducible nitric oxide synthase (iNOS), which would attenuate the harmful effects of inflammatory cells in response to ischemic injury.

In summary, SPECT intuitively reflects the improvement in $\mathrm{rCBF}$, which is induced by CVFTbased FNS for the treatment of acute cerebral infarction. The increase of $\mathrm{rCBF}$ and amelioration of imaging corresponded to improved scores estimated by the neural ability defect test. Thus, we conclude that CVFT, including FNS, noticeably improves $\mathrm{rCBF}$ and accelerates the recovery of neural functions in acute cerebral infarction patients. 
All experimental protocols were in agreement with the international ethical norms and guidelines of the Ethics Committe of the Chongqing Medical University, Chongqing, China. Informed written consent was obtained from all subjects involved in the tests and also from attending physicians.

The authors of this study, Q. Li and J. Yang, confirm that the research and publication of the results were not associated with any conflicts regarding commercial or financial relations, relations with organizations and/or individuals who may have been related to the study, and interrelations of co-authors of the article.

\section{Л. Лi ${ }^{1}$, Ж. Янг ${ }^{1}$}

\section{ПОКРАЩЕННЯ РЕГІОНАЛЬНОГО КРОВООБІГУ В ГОЛОВНОМУ МОЗКУ ПІСЛЯ СТИМУЛЯЦЇ̈ $N U C L$. FASTIGIUS У ПАЦІЕНТІВ ІЗ ЦЕРЕБРАЛЬНИМ ІНФАРКТОМ}

\author{
${ }^{1}$ Перша клініка при Медичному університету Медичного \\ університету Чонгкі, (Китай). \\ P е 3 ю м е
}

Експериментальні дані вказують на те, що електрична стимуляція nucl. fastigius (FNS) посилює регіональний церебральний кровообіг та знижує інтенсивність його розладів. У нашій роботі ми досліджували впливи FNS та кореляцію відповідних ефектів із прогнозом при лікуванні пацієнтів із крововиливом у головний мозок. Характеристики регіонального кровообігу в головному мозку вимірювали перед FNS та після неї за допомогою однофотонної емісійної комп'ютерної томографії (SPECT); отримані дані піддавали напівкількісному аналізу. Прогностичний аспект оцінювали за результатами тестування неврологічних дефектів. В обстежених пацієнтів спостерігалися різні рівні зменшення регіонального церебрального кровообігу. Фокальна FNS помітно згладжувала розлади кровообігу як у зоні інфаркту, так і у відповідних контралатеральних ділянках головного мозку $(P<0.05)$. Зображення, отримані за допомогою $\mathrm{SPECT}$, свідчили, що покращення регіонального кровообігу сильніше виражене в зоні інфаркту, ніж у ділянках, оточуючих центральний район ураження. Таким чином, продемонстровано, що FNS призводить до посилення регіонального церебрального кровообігу в пацієнтів із крововиливом у головний мозок і це супроводжується покращенням клінічних симптомів.

\section{REFERENCES}

1. D. Sun, Y. Geng, Y. D. Zhang, et al., "Study of ${ }^{99 m}$ Tc-ECD SPECT and EEG in the evaluation of epilepsy patients treated by Cerebrolysin," Chin. J. Nucl. Med., 19, 37 (1999).

2. C. Y. Zhao, L. F. Zou, P. Xie, et al., "Effect of drug therapy on patients with cerebral infarction evaluated by cerebral perfusion imaging," Chin. J. Nucl. Med., 19, 228 (1999).

3. D. Sun, "A comparative study of ${ }^{99 \mathrm{~m}} \mathrm{Tc}-\mathrm{ECD}$ and X-CT in the evaluation of patients with cerebropathy," Chin. J. Nucl. Med., 15, 171-173 (1995).

4. M. Nakai, C. Iadecola, D. A. Ruggiero, et al., "Electrical stimulation of cerebellar fastigial nucleus increases cerebral cortical blood flow without change in local metabolism: evidence for an intrinsic system in brain for primary vasodilation," Brain Res., 260, 35-49 (1983).

5. H. Nagasawa and K. Kogure, "Correlation between cerebral blood flow and histologic changes in a new rat model of middle cerebral artery occlusion," Stroke, 20, 1037-1043 (1989).

6. Y. Xia, Y. Luo, and W. Dong, "Effect and mechanism of fastigial nucleus stimulation on stroke in rats," J. Apoplexy Nerv. Dis., 16, 3-5 (1999).

7. L. Qi, "Advance in fastigial nucleus electrical stimulation for ischemic brain injury," Int. J. Cerebr. Vascul. Dis., 1996, 3335 (1996).

8. J. Yang, W. W. Dong, and Y. B. Zhang, "A preliminary study on human cerebrovascular diseases with electrical stimulating postcranial fossa," Acta Univ. Sci. Med., 23, 126-129 (1998).

9. S. Yamamoto, E. V. Golanov, and D. J. Reis, "Reductions in focal ischemic infarctions elicited from cerebellar fastigial nucleus do not result from elevations in cerebral blood flow," J. Cerebr. Blood Flow Metab., 13, 1020-1024 (1993).

10. C. Iadecola, M. Nakai, E. Arbit, et al., "Global cerebral vasodilatation elicited by focal electrical stimulation within the dorsal medullary reticular formation in anesthetized rat," J. Cerebr. Blood Flow Metab., 3, 270-279 (1983). 